\title{
"Of rose and pomegarnet the redolent pryncesse": Fashioning Princess Mary in 1525
}

\author{
STEPHEN HAMRICK
}

Minnesota State University Moorhead

While a more accurate appraisal of Mary Tudor's life and reign is underway, historians of literature continue either to ignore or to misinterpret surviving representations of Princess Mary. To begin correcting this failure, the article analyzes a complex 1525 verse portrait of Mary, setting that text within its contemporary political contexts. Analysis of William Newman's unpublished manuscript poem, "My ladie princesse doughter to king harry the VIII," recovers an intriguing characterization of the first Tudor princess in the period immediately prior to Henry's divorce from Catherine of Aragon and frustrates attempts to understand the first Tudor queen as a lifelong loser destined to failure by her own limited abilities. Newman's long poem represents the princess as uniquely qualified and admirably prepared to rule England as Henry's heir.

Bien qu'une réévaluation de la vie et du règne de Marie Tudor soit en cours, les historiens de la littérature continuent d'ignorer ou de mal interpréter les représentations de la princesse Marie qui nous sont parvenues. Afin de contribuer à corriger cette lacune, cet article analyse un portrait littéraire complexe de Marie, long de 1525 vers, et le situe dans son contexte politique. L'analyse du poème manuscrit et inédit de William Newman, intitulé "My ladie princesse doughter to king harry the VIII", présente une intéressante description de la première princesse Tudor, durant la période précédant immédiatement le divorce d'Henri VIII et de Catherine d'Aragon; ce choix chronologique empêche de considérer la première reine Tudor comme une perdante, que ses compétences limitées destinent à l'échec. Le long poème de Newman représente en effet la princesse comme l'héritière d'Henri VIII, exceptionnellement compétente et parfaitement préparée à diriger l'Angleterre.

$\mathrm{W}$

ithin the last decade, biographers and historians have substantially revised our understanding of Mary Tudor, eldest child of Henry VIII and first queen regnant of England. Rather than the intellectually, religiously, and physically sterile "Bloody Mary" characterized by Protestant historiographers like John Foxe, twenty-first-century scholars have uncovered an accomplished royal princess and effective queen. Historians now see Mary's reign and church as complex and successful, if short-lived ${ }^{1}$-and not simply as a stagnant period

1. Such corrective readings include Alice Hunt and Anna Whitelock, eds., Tudor Queenship: The Reigns of Mary and Elizabeth (New York: Palgrave, 2010); Eamon Duffy, Fires of Faith: Catholic England Under Mary Tudor (New Haven: Yale University Press, 2009); Anna Whitelock, Mary Tudor: Princess, Bastard, Queen (New York: Random House, 2009); Judith Richards, Mary Tudor (Oxford: Routledge, 2008); 
of religious oppression and ineffective ministry. However, some scholars continue to ignore or misinterpret surviving representations of Princess Mary.

Although Henry VIII discounted Princess Mary, her education, and her political ability, she and her mother, Queen Catherine, worked hard to prepare the young royal to rule. ${ }^{2}$ Rather than simply ready Mary "for the inevitable marriage negotiations" where she would fulfill "her role as political pawn,"3 Catherine "attempted to promote," as Aysha Pollnitz establishes, "Mary's status as Henry's heir through the princess's schooling." ${ }^{4}$ Demonstrating clear accomplishments in music, dancing, and languages by the summer of 1525 , Mary left for the Welsh marches as the de facto Princess of Wales, heading a decidedly royal household. ${ }^{5}$ Such an apparent victory failed, however, to ensure her political position because, at the same moment, the king sumptuously ennobled his bastard son, Henry Fitzroy, offering a male alternative to the presumptive female heir, Mary. ${ }^{6}$ The king created further uncertainty by neither legitimizing the bastard Fitzroy nor officially recognizing Mary as the Princess of Wales. Such characteristically mixed signals compelled Mary and her supporters to begin a public relations campaign designed to affirm her uniquely royal identity. In contrast to the argument that Mary remained "at a loss to

Linda Porter, The First Queen of England: The Myth of Bloody Mary (New York: St. Martin's Press, 2007); and Eamon Duffy and David Loades, eds., The Church of Mary Tudor (Farnham: Ashgate, 2006).

2. Aysha Pollnitz, Princely Education in Early Modern Britain (Cambridge: Cambridge University Press, 2015), 234-35, 240-41.

3. Timothy Elston, "Trasformation or Continuity? Sixteenth-Century Education and the Legacy of Catherine of Aragon, Mary I, and Juan Luis Vives," "High and Mighty Queens" of Early Modern England: Realities and Representations, ed. Carole Levin, Jo Carney, and Debra Barrett-Graves (New York: Palgrave, 2003), 21.

4. Pollnitz, 230. On this contested point, see also, Sarah Duncan, Mary I: Gender, Power, and Ceremony in the Reign of England's First Queen (New York: Palgrave, 2012), 3; Andrew Taylor, “'Ad Omne Virtutum Gensu'? Mary between Piety, Pedagogy and Praise in Early Tudor Humanism," Mary Tudor: Old and New Perspectives, ed. Susan Doran and Thomas Freeman (New York: Palgrave, 2011), 107; and Judith Richards, "Mary Tudor: Renaissance Queen of England," in "High and Mighty Queens," 31.

5. On this household, see Jeri McIntosh, "A Culture of Reverence: Princess Mary's Household 1525-27," Tudor Queenship, 113-26. See also, David Starkey, Six Wives: The Queens of Henry VIII (New York: HarperCollins, 2003), 200-02.

6. Henry also began the long process of divorcing Catherine in 1525, but it remains unclear if either Catherine or Mary were immediately aware of this fact. On Fitzroy, see Beverley Murphy, Bastard Prince: Henry VIII's Lost Son (Stroud: Sutton Publishing Limited, 2001). 
know how to express" "her own royalty," the following analysis establishes that she and her supporters knew exactly how to represent her as princess. William Newman's manuscript poem, "My ladie pryncesse doughter to king harry the VIII," in fact, celebrates Mary's role as the Princess of Wales. A successful and educated member of her household, the devoutly Catholic Newman reminds the political nation of Mary's superlative claim to the English throne. Through classical and Christian figures, the political poem represents Mary as divinely and uniquely qualified for the role.

Early modern readers, moreover, appear to have understood the political nature of the text, as evidenced in the fact that someone bound it with another political text directed to elite (royal) readers and their supporters. An unknown reader has bound the quarto vellum manuscript-London, British Library, Additional MS 11814-with a (partial) Middle English verse translation and presentation of Claudian's poem De Consulatu Stiliconis (ca. $440 \mathrm{CE}$ ), which constructs a positive image of Richard, Duke of York, in 1445. Richard later governed as Lord Protector, dying in battle while attempting to take the throne by force. ${ }^{9}$ Cast in a medieval tradition of the mirror for magistrates, the fifteenthcentury packaging of De Consulatu praises Richard's fitness to rule as part of a "whispering campaign" at a time when his political position seemed uncertain. ${ }^{10}$ Newman's 1525 poem champions Mary as a doubly royal princess fit to rule at a moment when her political position also seemed uncertain; bound with De Consulatu, "My ladie pryncesse" offers a layered political portrait designed to distinguish Mary positively from any rival. Jeri McIntosh has noted that the

7. David Loades, Mary Tudor (Stroud: Amberley, 2012), ch. 13. For a review of those who interpret Mary as flawed, see Doran and Freeman, ed., 13-14; and Richards, 'Renaissance Queen," 27-28.

8. London, British Library, Additional MS 11814, ff. 26v-29v.

9. John Watts, "Richard of York, Third Duke of York (1411-1460)," Oxford Dictionary of National Biography (Oxford: Oxford University Press, 2004).

10. On the political nature of the 1445 translation, see Daniel Wakelin, Humanism, Reading, and English Literature 1430-1530 (Oxford: Oxford University Press, 2007), 77. See also A. S. G. Edwards, “The Middle English Translation of Claudian's De Consulatu Stilichonis," in Middle English Poetry: Texts and Traditions: Essays in Honour of Derek Pearsall, ed. A. Minnis (York: York Medieval Press, 2001), 267-78; Sheila Delany, "Bokenham's Claudian as Yorkist Propaganda," Journal of Medieval History 22.1 (1996), 83-96; and John Watts, “De Consulatu Stiliconis: Texts and Politics in the Reign of Henry VI," Journal of Medieval History 16.3 (1990): 251-66. 
poem defines Mary as "worthy by blood and nature to rule," yet the complex portrait Newman offered remains unanalyzed. ${ }^{11}$

The poem's only editor, A. S. G. Edwards, recognizes the political nature of the text. While hesitating to affirm a specific reading, Edwards suggests that

the poem was intended to offer some form of literary praise that is political in intent: to extol those qualities that might be held to be appealing by those engaged in negotiations about a possible engagement for Mary. However, it is not easy to see how this poem would have helped their cause, nor in what form(s) it might have circulated. ${ }^{12}$

This present article, if not attempting to read a specific "engagement for Mary" into the poem, will, nonetheless, outline the ways in which the text "helped their cause."

\section{"the highe aulter of Harlowe"}

Newman's poem, "Myladie pryncesse doughter to king harry the VIII," celebrates Mary's role as the Princess of Wales, dubbing her "my mastresse" (94), yet scholars remain unable to definitively identify Newman or his position within her affinity. Daniel Wakelin suggests that the writer of "My ladie pryncesse" may be the contemporaneous William Newman of Harlow, Essex (d. 1558), whose location in "Essex is only 35 miles from Clare in southern Suffolk, where the poem [...] was composed and probably copied." ${ }^{13}$ Although not conclusive, analysis of Newman's will in light of the poem supports Wakelin's suggestion.

Mixing traditional piety with a respect for education, the will writer embodies concerns that emerge fully in the poem. According to his will, Newman left a large family as well as property in both Harlow and London. In standard form, he first bequeaths his soul to "my lorde my Godde the holye familie the ffather Jesus Christ his sonne and the holy goost three personnes and all the one godde to rest in heaven with the moost gloriouse virgyn marie

\section{McIntosh, 121.}

12. A. S. G. Edwards, “A Poem on Princess Mary Tudor, 1525,” Nottingham Medieval Studies 55 (2011): 287.

13. Email to the author, 3/7/2016. See also, Wakelin, $74 n 44$. 
and all the holye companye of saynts and angells." In addition to leaving gifts (coal) for the poor in both locales, he willed very traditional bequests to "the highe aulter of Harlowe or the divine [?] there to praye for my soule and all my childrens soules" (47r).${ }^{14}$ Bequests for altars and prayers for the souls of the dead constitute Catholic practices later outlawed by Protestants. ${ }^{15}$ Taking effect at his death after Elizabeth came to the throne in 1558, his bequests identify Newman as a staunch Catholic. Along with an education-friendly bequest directed to the upbringing, "scholynge and bookes" (47v), of a ward, such evidence of the educated testator's Catholic sensibilities corresponds to the sensibilities expressed in "My ladie pryncesse", as well as by her known supporters. As such, "it seems," as Edwards writes, "reasonable to suppose that" Newman "was a member of Mary Tudor's household." ${ }^{16}$ Regardless of the poet's exact place within the princess' affinity, the poetic text serves as sophisticated and timely propaganda.

Its politically transgressive nature suggests that the poem probably circulated only among like-minded members of Mary's household, made up of both elite and "middling" readers; the lack of multiple surviving copies of the poem suggests a limited readership. Nevertheless, circulation of the manuscript poem within Mary's household replicated the broader set of political concerns current in multiple forms more broadly within Henrician England.

\section{"exelence in most fresche aray"}

Composed of twelve eight-line ballad stanzas, the laudatory poem fashions a complex portrait of Mary by deploying an abundance of mythological and religious allusions through an intermittent alliterative pattern and a Latinate diction. ${ }^{17}$ The poem generates a narrative arc that represents Mary's royal

14. National Archives, MS PROB 11/43, ff. $47 \mathrm{r}-48 \mathrm{r}$.

15. On bequests for altars and prayers for the dead during Elizabeth's reign, see Eamon Duffy, The Stripping of the Altars: Traditional Religion in England 1400-1580 (New Haven: Yale University Press, 1992), 565-69.

16. Edwards, "A Poem on Princess Mary," 288.

17. On the poem's style, see Edwards, “A Poem on Princess Mary," 287-88. 
development from birth to a glorious future in which she rules with a powerful royal husband blessed by God and "every englysshe hart" (line 89). ${ }^{18}$

Both evoking Mary's birth (1516) and casting the contemporary moment of 1525 as providential, "My ladie pryncesse" starts by asserting a new beginning for Mary and readers through layered classical allusion. Introduced "in the mornyng clere after the clowdy nyght" and, for good measure, alongside the Roman goddess of childbirth, "Lusyna in the dawnyng day" (lines 1-2), Mary's presence, notably "excludyng pervers Pluto" (line 3)-the god of the underworld, here tonally embodying wickedness and death-brings light and hope to the world. In a 1525 text directed to "My ladie pryncesse," such hope logically refers to Mary's new role as governor in the traditional principality of the heir apparent. To accentuate the international reputation and power of his dynasty, in fact, Henry established a royal court for Mary as de facto Princess of Wales, which departed for the marches in August 1525.

Represented as a rebirth for all the world, Mary's new position also provides the long-term assurance of political and personal stability so keenly pursued by the crown. Promoting this assurance, Newman celebrates the fact that, with the help of "Dame Floras exelence in most fresche aray," Mary "hathe sprede the sentes aromatyque in ther garments gay" (lines 4-5). As the Roman goddess of flowers and, by 1523, the English "quen / of Somer" (line 12v), Newman's “Dame Flora” represents Mary's politically significant ability to produce children - the poem's metaphoric "flowers" - and the glorious summer in which she became the Princess of Wales. ${ }^{19}$ In this fecund image, then, Mary's service dispels the malaise represented through the classical allusion to deathly Pluto and by the sometime lack of royal presence in the eastern marches.

Although the Holy Roman Emperor, Charles V, recognized the limited political advantage of his temporary engagement to Mary, he too represented her as a vibrant, life-giving figure much as Newman had. ${ }^{20}$ In addition to complimenting "the manifold seeds of virtues that were in her," Charles lauded Mary's health and education; he also noted the emerald ring she sent, strategically promising that he would wear it for her sake during the remainder

18. All citations are taken from Edwards, "A Poem on Princess Mary" and will be cited parenthetically in the text.

19. The "quen" of summer comes from John Skelton, A Ryght Delectable Treatyse Upon a Goodly Garlande or Chapelet of Laurell (1523), STC 22610, n.p.

20. Pollnitz, 229, asserts that "the diplomatic fiction that Mary was Henry's heir soon wore thin." 
of his life. ${ }^{21}$ Mary's accompanying message avowed that the ring represented her constancy and that she jealously hoped "his Ma[jes]tie dothe keepe him selfe as contynente and chaste as with goddes grace she will." ${ }^{22}$ Whether Mary expressed these concerns herself, the sentiments embody contemporary expectations of "chaste" female gender identity even as they actively construct a second royal identity in which the much older Charles "doth keep constant" to the young princess. Such rhetorical positioning offers both a traditional, non-threatening portrait of feminine chastity and a non-traditional assertion of agency, assigning a specific and "constant" role to the emperor. In this 1525 missive, Mary participates in a process of assertive self-fashioning within a competitive discourse that includes representations of the royal princess, such as Newman's, constructed outside of crown control.

To what degree, if any, Mary comprehended her complex position remains unclear, yet such a critical concern ignores the multivocal, communal, and contested nature of royal iconography. Even if, as John Edwards argues, "in her teenage years," and earlier, "Mary continued to be recipient of other people's actions, rather than taking initiatives of her own," ${ }^{23}$ such a claim disregards the practical fact that the monarch and other royals required extensive help in building and maintaining their public identity. In "selling" the monarchy, as Kevin Sharpe and others establish, monarchs required a broad range of individuals to run their public relations machine, including counsellors, artistic "impresarios," and many others. Beyond servants of the crown, other agents deployed royal images for different purposes. ${ }^{24}$

Significantly, when he came to the throne amid a flurry of royal images in 1547, Edward VI had reached the same age as nine-year-old Mary when she first emerged (semi-) publicly in the 1525 "My ladie princesse." Scholars confidently affirm that the young Edward came to the throne fully cognizant of and committed to his royal identity as an imperial, godly monarch dedicated

21. J. S. Brewer, James Gardiner, and R. H. Brodie, eds., Letters and Papers, Foreign and Domestic, of the Reign of Henry VIII, 37 vols. (London: Longmans, 1862-1932), 4:611.

22. Quoted in Frederick Madden, Privy Purse Expenses of the Princess Mary (London: William Pickering, 1831), xxxv. See also Hunt and Whitelock, eds., 26.

23. John Edwards, Mary I: England's Catholic Queen (New Haven: Yale University Press, 2011), 18.

24. Kevin Sharpe, Selling the Tudor Monarchy: Authority and Image in Sixteenth-Century England (New Haven: Yale University Press, 2009), 64-69. On the multiple sources of royal iconography, see also John King, Tudor Royal Iconography (Princeton: Princeton University Press, 1989), 18. 
to religious reform. ${ }^{25}$ Traditions of Protestant-Whig historiography and an implicit sexism, then, have reconstructed two nine-year-old children as radically different in their self-awareness and command of royal iconography. Mary's youth did not prevent her from developing and manipulating her royal image; many astute writers throughout Europe, including Newman, understood Mary's symbolic and political value, deploying a range of complex royal images of the princess in pursuit of their own goals and, at times, hers.

\section{"representyng thys most goodly may"}

Ending the poem's first stanza with both classical and personal allusions, Newman crafts a usefully protean portrait of Mary, which further constructs her life-giving nature as well as her political position within both Henrician England and Catholic Europe. Evoking Apollo, the classical god of light and the sun, Newman's speaker populates the metaphoric garden of the world, or Henry's realm, with

The fatall flowrys of feture shynyng in exesse

$\mathrm{O}[\mathrm{f}]$ Phebus representyng thys most goodly may,

Of rose and pomegarnet the redolent pryncesse. (Lines 6-8)

In presenting such a classically shaded portrait of Princess Mary, here and throughout the poem, Newman deploys multiple mythological figures, subsuming both masculine and feminine symbols within an extended organic metaphor. This address to the sun god, Phoebus Apollo, the god of lifegiving light, of the muses, and of poetry, tropes Mary's beauty and character, "representyng" it as divinely fecund and visibly true. The redolent "fatall flowrys of feture" further represent the life-giving and flower-blooming month of May and, therefore, Mary's politically innervating elevation as the Princess of Wales. As a "fatall" or fated (OED 1-4) flower, Mary also receives the ideological 
sanction of "fate" or Providence, inaugurating a divinely approved and new "season" through both Apollo's blessing and God's beneficent will. ${ }^{26}$

Heraldic and metonymic emblems for the English and Spanish monarchies, the rose and pomegranate evoke Mary's international heritage and serve together as her personal symbol. Repeated twelve times in the poem, the refrain "Of rose and pomegarnet" fashions Mary's Spanish lineage as a central element in her political identity. From late 1522, in fact, Mary's engagement to the Holy Roman Emperor, the Spanish Habsburg, Charles V, placed her-very much as Newman does-at the centre of European politics. During the summer of 1525, on the eve of taking up her duties as the de facto Princess of Wales, the royal (specifically Anglo-Spanish) identity of nine-year-old Mary worried those in power. In a letter to Henry VIII, dated June 2, English ambassadors informed the war-hungry king that his imperialist plans to invade France with the aid of the emperor hinged upon their failing negotiations concerning Princess Mary; Henry's "Great Enterprise" sought to conquer France and make it a part of his domain. Such an all-consuming passion compelled him repeatedly to use his only child as a significant weapon in his political arsenal.

Wishing to achieve political and economic advantage, the emperor informed Henry that if the English monarch funded the war by paying Mary's delayed dowry and sent Mary to live in Spain, he would join the English prince in waging war. Charles asserted that, residing in Spain, Mary and her council would prevent a domestic revolution while he campaigned with Henry. ${ }^{27}$ Unable to cede such political advantage, and with no hope that the emperor would otherwise join Henry in France that summer, the ambassadors reminded the king that he "thankfully" possesses "my lady Princess in your own hands" because "many great princes may be kept in hope of having her till she come of age." ${ }^{28}$ Ambassadorial letters to both Henry and Thomas Wolsey reiterated such a claim, indicating that "with much thank[s] my lady Princess [remains] in your hand," stating that she "is a pearl worth the keeping" or a valuable commodity in political negotiations. ${ }^{29}$

26. All definitions are from Oxford English Dictionary Online (Oxford University Press, March 2017) and will be cited parenthetically in the text.

27. Letters and Papers Henry VIII, 4.612.

28. Letters and Papers Henry VIII, 4.615.

29. Letters and Papers Henry VIII, 4.617, 4.634. In both places, the editor has quoted the manuscript directly. 
Still other decision makers recognized her potentially useful role in European power struggles. The emperor would shortly wed Isabella of Portugal, yet he communicated to Henry that he remained aware of "the advantages of the [English] match, and the prospect, if Henry had no issue, of England being annexed to Spain and Flanders." ${ }^{30}$ In July 1525, the English ambassadors provided an equally frank response. They reported to Henry their words to the emperor, that as the princess

Was your only child at this time in whom your Highness put the hope of propagation of any posterity of your body, seeing the Queen's grace hath been long without child; and albeit God may send her more children, yet she was past that age in which women most commonly are wont to be fruitful and have children. ${ }^{31}$

Although the ambassadors would also convey the crown's concern over Mary's health "if she were transported into an air so different from that of England," her position as Henry's "only child" and "hope of [...] any posterity" dominated contemporary representations of the princess. In this light, the use of the childbirth goddess Lusyna in Newman's first stanza markets the princess as a fertile solution to Henry's problematic inability to produce a male heir. Mary's value as heir, moreover, also stemmed from her Spanish mother, Catherine. As such, the crown argued, Mary need not be raised in Spain, for if the emperor

Should seek a mistress for her to frame her after the manner of Spain, and of whom she might take example of virtue, he should not find in all Christendom a more meet than she now hath, that is to say, the Queen's grace her mother, who is comen of this house of Spain, and who, for the affection she beareth the Emperor, will nourish her, and bring her up as may be hereafter to his most contentation. ${ }^{32}$

Offering a rhetorically unaggressive reason for denying the emperor's request, the ambassadors connect the nine-year-old Mary to her Spanish relatives 
through "the Queen's grace her mother." "Comen" or originating "of this house of Spain," Catherine continues to "nourish" the princess "after the manner of Spain," forming her in England as a suitably international or Hispanophile royal mate.

Simultaneously writing to "every englysshe hart" and evoking an international Anglo-Spanish pedigree for Mary, the verse panegyric accentuates a unique royal identity for her. Embodying Mary's superiority and distinction, then, "My ladie pryncesse" begins by deploying the luminescent and fecund figures of Lusyna, Dame Flora, and Phebus alongside Mary's august Spanish heritage to advertise that her value and/or political agency as a "redolent pryncesse" derives from many sources: primarily the "rose and pomegarnet," or her parents.

\section{"of exaltacion erthely"}

The second stanza of the poem continues to fashion Mary's youthful development as a future royal ruler through other mythological and organic figures. The text constructs a blessed young princess by calling upon a female divinity, requesting

Pallas in the presen $[\mathrm{t}]$ prevocacyon plesant,

Governe and gyde owre prynces exelent,

Dessendyd regally of the royall plant,

Regysteryd tryhumphall in every regyment

Of exaltacyon erthely renomyde splendent. (Lines 10-14)

Although not present in the Oxford English Dictionary, "prevocacyon" seems to imply "pre-vocation." In this sense, Newman calls upon Pallas to guide Princess Mary in the enjoyable present as she prepares to take up her divinely appointed duty or "vocacyon" as the Princess of Wales. As Mary departed for Wales in August, these lines suggest that Newman wrote the poem sometime between May and September 1525.

Nevertheless, as a kind of poetic baptism for Mary, these lines cast the goddess Pallas (Athena or Latin Minerva) as a type of wise godmother who "gyde[s] owre prynces excelent." Newman constructs such "royall" and possessive ("owre") excellence as an inherited trait, naturalizing the royal 
family's grace through the ideological metaphor of descent from "the royall plant." Although the future of Henry's line remains increasingly doubtful in 1525 , due to his lack of a male heir, the manuscript poem works assiduously to affirm the solidity of the family line, asserting baldly that Mary "dessendyd regally." The poetic vagueness of this descent-paired with the organic resilience of the metaphoric "plant"-implies a much greater dynastic longevity than that actually enjoyed by Henry in the first quarter of the sixteenth-century. Despite the fact that Henry VII possessed a relatively weak claim to the throne, the poetic paean elides such lineal embarrassment through layered hyperbole. ${ }^{33}$

In the space of two lines, Newman deploys four pairs of terms that further define Henry's dynasty as firmly established, hugely famous, and fated to succeed through Princess Mary. In line 12, the combination "Regysteryd tryhumphall" deploys the past tense to indicate that recorded history has already "registered" (OED 1a, b, d) Henry's victory. The poem fails to offer any indication of how Henry has achieved such a shining victory, yet the term "tryhumphall," evoking images of victorious entry processions or "triumphs," implies that others recognize such a visible success (OED 1-6). Through the hyperbole of "every regyment," moreover, Newman rhetorically evokes a universal or, more precisely, European impact for Mary's dynastic victory, which the metaphoric term "regyment," meaning "rule or government" (OED 1a), suggests. The refrain "Of rose and pomegarnet" again announces Mary's Spanish lineage, here suggesting that "every regiment" includes her Spanish grandmother, Queen Isabella of Castile, who fought for and won the Spanish throne of Castile-in spite of having been disinherited by her father. ${ }^{34}$ As the only successful queen regnant in early sixteenth-century Europe, Isabella represents the kind of potent monarch praised by Newman as he constructs Mary's future promise.

The manuscript poem "My ladie pryncesse" further structures Mary's unique reputation and political agency through line 13's oxymoronic "exaltacyon erthely," which combines spiritual and material discourses in useful tension. Suggesting a religious or emotional rapture, as well as the assumption of royal sovereignty (OED 2a, b), "exaltacyon" again represents Mary as divinely

33. Thomas Penn, Winter King: Henry VII and the Dawn of Tudor England (New York: Simon \& Schuster, 2012), 21.

34. On Isabella, see Alexander Samson, "Power Sharing: The Co-Monarchy of Philip and Mary," Tudor Queenship, 160-62. 
appointed, yet simultaneously recognized in the earthly or political sphere as royal and sacred. The final pairing of "renomyde splendent" economically reiterates the wide-spread or renowned (French, renom) reputation of their metaphorically visible, i.e., "splendent" and stunning, victory.

Newman promotes Mary's value as Henry's heir not simply through her past role as living evidence of the king's dynastic success, but through her present and future role as mother of kings. Stanza 2 vocatively characterizes the princess, proclaiming her

O radyent Polexena of bownteus encresse,

Fowntayne of delight, most noble parent

Of rose and pomegarnet the redolent pryncesse. (Lines 14-16)

Representing superlative beauty as the "fayrest mayde that was in her tyme," Princess Polyxena, daughter of Trojan King Priam, transitively represents Mary's generative beauty. ${ }^{35}$ Such beauty, however, resides not in physical appearance alone, but in "bownteous encresse," i.e., in Mary's ability to serve as a delightful "fowntaye" and "noble parent / Of" the future heirs of Henry (the English "rose") and Catherine (the Spanish "pomegarnet"). These images seem apropos to such a concerned monarch sixteen years into his reign and lacking a legitimate male heir. As subtly suggested in the Emperor's comments, Henry increasingly defined his lack of a male heir as a divine punishment. By contrast, Newman celebrates the king's investment in his daughter as a singular and overwhelmingly powerful heir.

Set within such familial and spiritual contexts, Princess Mary emerges as a vivifying scion of her house, promising political continuity and, as the incessant refrain declares, assured political acuity arising from her unique combination of English and Spanish-Habsburg blood. Representing her, as Henry's ambassadors had, "after the manner of Spain," Newman thus deploys the crown's own contemporary iconography of Mary, yet makes such a move in order to consolidate her position and not Henry's.

35. On Polyxena, see William Caxton's translation of "The Recuyell of the Historyes of Troye (1473), Bk. 3, "Of Them That Were Within Troye," STC 15375, n.p. 


\title{
"the redolent princesse"
}

Newman further paints his marketing portrait of Mary with allusions to Minerva, the goddess of just war, wisdom, and the arts. The poem reinforces Princess Mary's divine right to rule by asserting that "Mynerve hath made the state imperyall" (line 17). In this image, Mary embodies the wisdom and warrior spirit of Minerva, suggesting that she will fight for God and her father to maintain the "state imperyall." Springing classically from the head of Jupiter, Minerva here allegorizes Mary as the puissant heir of Henry VIII. Significantly, contemporary artists regularly represented Henry through the figure of Jupiter. Newman's use of "Minerva" thus evokes "a contested mythological narrative, a story in which Jupiter was potentially either a conquering hero or a usurping tyrant." ${ }^{36}$ Here, in the first part of the stanza, with Jupiter's presence only implied, Mary's inherited strengths advertise her, and not her father's, agency.

Further deploying this usefully martial ethos, the stanza thereafter strategically transfers King Henry's religiously-coded martial agency to Princess Mary. The poem also doubly evokes her mother, Queen Catherine, to further constitute an aggressive religious agency for her. Mary descends, significantly, from two martial parents:

\author{
The spanyshe br[i]de of desent royall \\ In thys nacyon of noble mantayne, \\ With rosa v[ir]tutis regently to rayne, \\ Fidei defensor by marcyall prowesse, \\ Thys glorefyde graffe dothe thus remayne, \\ Of rose and pomegarnet the redolent pryncesse. (Lines 19-24)
}

Although Henry, as the Latin "rosa virtutis" or potent rose, reigns with martial prowess, here the royal "spanyshe br[i]de" will be the one to "mantayne" "thys nacyon of noble" men and women as the religious warrior-king, Henry VIII, had done. In 1521, Medici Pope Leo X named Henry VIII "Fidei defensor" or "defender of the faith" for his rejection of Lutheran theology in his Defense of the Seven Sacraments published the same year. For encouraging other

36. Greg Walker, Writing Under Tyranny: English Literature and the Henrician Reformation (Oxford: Oxford University Press, 2005), 112. 
anti-Lutheran publications, Queen Catherine also received the title of "fidei defenstrix" from her Spanish confessor who also wrote against Luther. ${ }^{37}$ As such, the third stanza of "My ladie pryncesse" clarifies one meaning of the refrain that dubs her "the redolent pryncesse." Combining "state imperyall," "nacyon," "fidei defensor," and "marcyall prowesse," the verse encomium seizes upon Henry's militant foreign and conservative religious policies to fashion a pious militant dynasty represented by the powerful princess and also, as we noted from the Emperor's letter, by her Spanish forebears and equally anti-reformist mother, Queen Catherine.

\title{
"consyderyng nobylete in thys creature"
}

While thus accentuating Mary's martial and religious agency as "the redolent pryncesse," Newman nevertheless magnifies her unique nature as the only legitimate child of Henry VIII. Stanza four of "My ladie pryncesse" repeatedly constructs Mary's purity and nobility through comparative syntax, as well as through representations of divine processes. Further constructing the young noble's divine nature, Newman describes

\author{
Phebus hys bealmys of depuryd gowlde \\ Wythe rayes reluysent castyng vygure, \\ Hath introvysyde the cyrcuyte enrowlde \\ Of thys p[er]fecte pucell, passying in nature \\ The clene copulacyon of formall stature, \\ Comprysyd only the well of ientylnesse \\ Consyderyng nobylete in thys creature \\ Of rose and pomegarnet the redolent pryncesse. (Lines 25-32)
}

The text here replicates an incessant, almost neurotic, focus on Mary's perfect purity and inborn "nobylete." Phoebus Apollo's fructifying beams and "rayes" purify the princess by "castying vygure" or strength upon Mary. Moreover, the "cyrcuyte" or roundabout journey (OED 3b) "enrowlde" or recorded on a register (OED 1) allegorizes Mary's life (or her trip to Wales) as infused

37. On Henry and Catherine, see John Wagner and Susan Walters Schmid, eds., Encyclopedia of Tudor England. 3 vols. (Santa Barbara: ABC-CLIO, 2011), 1:340; and Maria Dowling, "A Woman's Place?: Learning and the Wives of Henry VIII," History Today 41.6 (1991): 38. 
with religious or divine life while, at the same time, long in the making. The superlative "passyng in nature" suggests that Mary's excellence surpasses any "formal stature" or physical body, yet "stature" in the sixteenth century also means place or position (OED 4), which offers further political symbolism. The text also indicates that Henry's royal daughter is "comprysed only" of "ientylnesse," i.e., the inherited nature of being born noble or "gentle."

Building upon these comparative formations, Newman constructs her royal status when he directs readers to the act of "consyderyng" the "nobylete in thys creature." As such, Mary's inherent nature surpasses any place or position to which she might be compared. The comparison takes on greater significance by recalling that, in June 1525, Henry elevated his illegitimate son, Henry Fitzroy, to the dukedoms of Richmond and Somerset (among other honours) above all other non-royal nobility. In the repeated comparisons and focus upon Mary's inherent nobility of birth, Newman's text thus counters the political elevation of Henry Fitzroy, the king's bastard son, and his position as an alternative heir to the throne..$^{38}$ Unlike Mary, Fitzroy's investiture involved extensive formal and publicly celebrated ceremonies-echoing the terms "clean copulacion" or "act of coupling or linking two things together" (OED 1) and the "formall stature" that Mary syntactically surpasses in the poem.

\section{"as cheff governowre betwene strange realmys"}

Immediately following this veiled rejection of Henry Fitzroy's troubling and largely unprecedented elevation to a position of nobility, Newman focuses specifically upon Mary fulfilling the traditional princely duty of governing Wales. In his fifth stanza, which combines English, French, and Latin, the text compares Mary to a figure that usefully troubles stable notions of gender and gender performance. In an allusion that aptly focuses on a royal daughter transformed into a suitably married royal heir, Newman uses the classical figure Iphys to represent Mary as the perfect heir-despite her female gender. Newman compares the princess to

38. Edwards, in "A Poem on Princess Mary," 286, discusses the "political pressure," yet underestimates the political cachet Mary garnered by travelling to, what he stresses as, "the remoteness of the Welsh Marches." 
Iphys adyacent, in partys excessyff,

In the wawes wonderus of the salt stremys,

From every part, by pusant portatyff

As cheff governowre betwene strange realmys. (Lines 33-36)

Dismissing contemporary English concerns over her gendered identity, these lines use multiple classical allusions to construct Mary as the "cheff governowre" of Wales, serving both literally and figuratively between England and the marches of Wales. Initially, "Iphys adyacent" evokes Ovid's tale of a poor couple who require divine intervention to enjoy a male heir; as such, the allusion serves as a dismissive admission of both Henry's failure to produce a male heir and perceptions of Mary's gendered inability to fill that role.

Newman evokes an English revision of Ovid to represent the princess. From Ovid's Metamorphoses (Book 9.666-797) and retold in John Gower's Confessio Amantis (1483), Iphys was born a girl, transformed later by Egyptian Isis, and thereafter lived life happily as a married man. In Ovid, Iphys emerges as the son of an "undistinguished" man or, as Arthur Golding would translate in 1567, "a yeoman of the meaner sort." ${ }^{39}$ Newman's text, however, recalls the Confessio, as Gower recasts the story of Iphys, making him the son of "king Ligdus" who "upon a strif / Spak unto Thelacuse his wif" (451-52) and told her that, if she had a girl child, "that it ne scholde be forlore /And slain"(456-57); William Caxton's 1480 manuscript translation also revises Iphys's origins, dubbing his father Lygde, "a baron noble and ryche." ${ }^{40}$ As Gower writes, born a girl,

This Iphis was forthdrawe tho,

And clothed and arraied so

Ri[g]ht as a kinges sone scholde. (Lines 471-73)

39. Quotes from Ovid are taken from Anthony Kilne's 2000 translation, http://ovid.lib.virginia.edu/ trans/Metamorph.htm, and will be cited parenthetically in the text. Arthur Golding, trans. Ovid's Metamorphoses (1567), STC 18956, f. 121r.

40. Quotes from Gower are taken from Andrew Galloway's 2013 translation, http://d.lib.rochester.edu/ teams/publication/peck-gower-confessio-amantis-volume-2, and will be cited parenthetically in the text. William Caxton, trans. The Metamorphoses of Ovid. 2 vols. (New York: George Braziller, 1968), vol. 2, ch. 14, n.p. 
In collusion with the Egyptian mother goddess Isis, Queen Thelacuse saves her daughter. Dressed immediately "as a kinges sone" and thereafter raised as a boy, Prince Iphis would later be transformed physically into a young man in order to marry his/her beloved lady, Ianthe; when Ligdus arranges the marriage, he thus unknowingly places his child in a seemingly impossible situation. ${ }^{41}$ Ovid's story of gendered transformation or transgender identity works quite well in Newman's allusive construction of Mary as a female heir embodying traits normally considered male, yet Gower's and Caxton's royal recastings offer even greater relevance to Mary. Like Iphys, Mary enjoyed her royal mother's protection, even as Henry repeatedly promised her in marriage. Like King Ligdus, Henry VIII experienced "strif" with his own "wif" concerning an inability to produce a male heir.

Responding to the contemporary political moment through such allusions, Newman evokes the transgendered royal Iphis only to assert that Mary far surpasses the male prince "as cheff governowre" or Princess of Wales. Compared to the royal "Iphys adyacent," Mary's qualities, even considered individually or "in partys," shine in an "excessyff" manner or exceed those possessed by Iphis, Henry Fitzroy, or anyone else. Mary's excellence, moreover, circulates in a "pusant" or powerful manner,

By extremable fors hathe sprede her bealmys

Thorowghe owt the worlde, fame to presesse,

The muse tragydyall, with gret iubelemus,

Of rose and pomegarnet the redolent pryncesse. (Lines 37-40)

41. On Iphis, see Robert Mills, Seeing Sodomy in the Middle Ages (Chicago: University of Chicago Press, 2015), 98-105; Diane Pintabone, “Ovid's Iphis and Ianthe: When Girls Won't Be Girls," in Among Women: From the Homosocial to the Homoerotic in the Ancient World, ed. Nancy Sorkin Rabinowitz and Lisa Auanger (Austin: University of Texas Press, 2009), 256-85; Liz Oakley-Brown, Ovid and the Cultural Politics of Translation in Early Modern England (Aldershot: Ashgate Publishing, 2006), 174-76; Michael Simpson, The Metamorphoses of Ovid (Amherst: University of Massachusetts Press, 2003), 357-59; and Diane Watt, "Behaving Like a Man? Incest, Lesbian Desire, and Gender Play in Yde et Olive and its Adaptations," Comparative Literature 50.4 (1998): 265-85. 
Mary's "fame" receives further serious celebration by the divine "muse tragydyall" or Melpomene, the muse of singing, tragedy, and serious poetry. ${ }^{42}$ As the muse of serious poetry and singing, Melpomene presses or spreads Mary's fame beyond Wales, "thorowghe owt the worlde," in fact, with "gret iubelemus" or jubelemus, the Latin for "jubilee" or celebration.

In these terms, Newman advertises Mary's new role as "cheff governowre betwene strange realmys," interpreting that role as Henry's confirmation that she serves as heir apparent. Not unlike the once-threatened female heir, Iphis, Newman's female Mary inhabits a traditionally masculine role as "Prince" of Wales; contemporaries would, in fact, refer to her both as "Prince" and "Princess" of Wales. ${ }^{43}$ Coded in terms of royal daughters, protective queens, and heir-obsessed misogynistic kings, Newman's Ovidian allusion, filtered through Gower (if not Caxton), asserts that Mary's gender transcends even the protean and/or royal figures of the ancient world; in a sense, Newman offers the princess a doubly-gendered iconography that she would not widely deploy-unlike her sister, Elizabeth. Newman also provides a pattern of representing the queen through female goddesses, which scholars normally see as an Elizabethan innovation. ${ }^{44}$ The comparison suggests that much as Iphis's transformation enabled him/her to continue the royal line, so too could Mary's transformation into the Princess of Wales enable her to achieve the same end. Although Queen Catherine, her nephew, Emperor Charles V, and her Spanish ladies-in-waiting each experienced (and some accepted) that a royal daughter could inherit the throne, Henry and most English decision makers rejected the idea. ${ }^{45}$ Within this context, then, Newman offers a poem that celebrates Mary as uniquely qualified to rule England as heir to her father who, in fact, used her

42. On Melpomene, see Edwards, "A Poem on Princess Mary," 293. See also, Robin Hard, The Routledge Handbook of Greek Mythology (London: Routledge, 2004), 205; Charles Blyth, "Virgilian Tragedy and "Troilus," The Chaucer Review 24.3 (1990): 211-12; and F. A. Todd, "Virgil's Invocation of Erato," The Classical Review 45.6 (1931): 217. In the period immediately before and after Newman wrote the poem, writers stressed Melpomene's role as a goddess of song. See, for example, Robert Henryson, Heire Begynnis the Traitie of Orpheus Kyng (1508), STC 13166, f. 6.3-4; and Robert Saltwood, A Comparyson Bytwene. Iiij. Byrdes (1533), STC 21647, f. 16.67.

43. Starkey, 201.

44. For example, see Stephen Hamrick, The Catholic Imaginary and the Cults of Elizabeth, 1558-1582 (Aldershot: Ashgate, 2009), 83.

45. Starkey, 198-200. 
in precisely this way to achieve diplomatic and political advantage throughout her young life.

\section{“Of Harry the eyght [...] With Kateryne queen”}

Building upon the classical, religious, and familial imagery deployed in the first half of the poem, stanzas 6 and 7 recall Mary's unique royal status through repeated recourse to her organic pedigree. Directly naming both of her parents, Newman again constructs Mary as normal and healthy, informing readers that

Nature hathe notefyde the semblance parsonable

Of thys plesant parsone, cheffe of owre delyght,

Comen of kynde to us most comfortable,

Of Harry the eyght, prynce most of myght

With Kateryne queen, the lanterne of owre lyght. (Lines 41-45)

Ostensibly praising an outwardly pleasant appearance, or "semblance," this stanza repetitively focuses upon Mary as a physically distinct being: as "parsonable," a "plesant parsone," and of a "kynde [...] most comfortable" or, as the $O E D$ indicates, pleasing to the senses (1a). Royal Harry's physical puissance and royal Catherine's enlightening wisdom combine, the stanza continues,

To shewe the course of natures besynes

Behowlde the parsone before your fatall syght,

Of rose and pomegarnet the redolent pryncesse. (Lines 46-48)

The allegorical mother Nature here works her business "to shewe" or display a glorious Princess Mary. With such profound care and creative ability as the source, the poem commands readers to visually "behowlde the parsone" presented.

Stanza 7 stresses Mary's descent from two royal houses in images that fashion a physically palpable sense of beauty, fecundity, and, above all, royalty. The consistent organic imagery imagines the princess as, again, a kind of prize botanical specimen growing in 
The pure presentacyon of parfytt grownde,

Graffyde in the garden of hyghe benyngnyte

Whose presyosyte dothe ever abownde

Syns other fruyte can not be fownde,

In the pomegarnet replet with goodnesse

Owre tunall tonges totally to sownde,

Of rose and pomegarnet the redolent pryncesse. (Lines 50-56)

Ostensibly a hyperbolic compliment asserting the impossibility of finding anyone as beautiful as Mary, line 53's "syns other fruyte can not be fownde" also metaphorically represents Mary as the only "fruyte" or legitimate heir to Henry VIII as crown ambassadors wrote earlier in the year, describing Queen Catherine as past the age when "women most commonly are wont to be fruitful and have children." Along with Newman's earlier stress on Mary's pure nobility, as well as the awareness that, as line 53 indicates, her nobility is not in doubt, this stress on Mary as the only royal fruit offers another oblique slight against Fitzroy. The degree to which Newman's floral and garden imagery relies upon medieval artistic and literary traditions lies beyond the present article, yet exploration of such traditions would prove fruitful. ${ }^{46}$

\section{"sum noble maryage"}

Building Mary's present superlative identity and her future role as a royal ruler, stanzas 8 and 9 dismiss the recent past by initially invoking the goddess of marriage, Juno. Magnifying Mary's desirability on the European marriage market, Newman addresses the goddess

Iuno of ioconde and ioyeous generacyon

Electe and chose sum noble maryage

Of regall prynces to shewe the presentacyon

In estate lykely to her ryall lenage,

Where as shall please her pusant parage,

46. On these traditions, see Arlyn Diamond, "Meeting Grounds: Gardens in Middle English Romance," in The Exploitations of Medieval Romance, ed. Laura Ashe, Ivana Djordjevic, and Judith Weiss (Cambridge: D.S. Brewer, 2010), 125-38; and Jack Goody, The Culture of Flowers (Cambridge: Cambridge University Press, 1993), 28-205. 
Allmyghty God, regarde her nobleness,

As is no dowght in the parsonage

Of rose and pomegarnet the redolent pryncesse. (Lines 57-64)

Crafting Mary's status as eminently, even divinely, marriageable, the text of "My ladie pryncesse" here asserts that the Princess of Wales will only be given in "noble maryage" to "regall prynces" who exist in "estate lyekly" or like unto "her r[o]yall lenage" or lineage; such a marriage, moreover, will please her "pusant parage," or powerful parents. More significantly, "Allmyghty God" attests to her nobility. Within the context of the summer of 1525, the poem's repetitive focus on Mary's attractiveness as a royal mate blessed by God erases any dishonour potentially caused by the failed engagements engineered by her father. Despite her current status, the poem reminds readers in stanzas 8 and 9 that there "is no dowght" that she is noble, because she comes from two royal lines. By contrast, Henry Fitzroy only derives from one and remains a bastard.

Returning to the effective classical allusions deployed earlier in the poem, Newman negates the impact of Henry's failed attempts to deploy the princess through political marriage alliances. Building upon Mary's identity as a providentially-directed royal and a beloved goddaughter to Mother Nature, "My ladie pryncesse" further represents the blessed nine-year-old as immune to the vicissitudes suffered by "mere" mortals. Joining the other Christian and classical caretakers, the goddess,

Fortune dothe floryshe the feture of her whele

The compass envyron in turnynge semblance

Exaltyng thys lady where as she dothe fele

No thyng erthely to her annoyance.

For why she owght to loke in plesance

What hart of stele wolde her oppresse

That is the only depuryd dalyance

Of rose and pomegarnet the redolent pryncesse. (Lines 65-72)

Here, Lady Luck or "Fortune" turns her notoriously fickle wheel on behalf of Henry's eldest child. Once again raised above all others, "exaltying thys lady," Mary "dothe fele / no thyng erthely." Immune to the vicissitudes of time and human action, Mary stands as a multiply-protected royal "lady" bound for 
greatness. All such ostensibly natural and supernatural aid, however, fails to erase Newman's fears, as the poem strangely asks "what hart of stele wolde her oppresse" (70). By questioning the potential oppression of a "hart of stele," Newman thus again evokes the negative tones created earlier through the terms "pervers Pluto" (3), roundabout "cyrcuyte" (27), "other fruyte" (53), "dowght" (63), and "annoyance" (68).

In the face of such recurrent negativity, which the poem admittedly qualifies as simply "annoyances," divine figures repeatedly protect the young royal girl, offering guidance and promising a future of active and successful rule. What readers might see as failed marriage attempts and alternative candidates for rule in England, Newman recasts as evidence of Mary's protected status and preparation for her assured noble marriage and eventual sovereignty. Promised a smooth path by Fortune and a noble marriage by Juno, Mary emerges in Newman's poem as an able scion of a militant and internationally powerful house recognized for both its wisdom and its religious orthodoxy. In a poem that deftly combines Christian and classical figures to fashion a redolent princess, Mary also receives the overt benison of both Saint Mary and the Christian deity.

\section{"Maria virgo justely the same"}

William Newman's "My ladie pryncesse doughter to kyng harry the viii” ends by combining classical and Christian figures to both protect and nurture young Mary. Again marketing Mary as internationally known and respected, in stanza 10 Newman places Mary's reputation in a clearly voluble voice, calling,

O famous trumpet with most noble sown[d]e,

The fleyng wynges of the horse of fame

Over sprede the worlde in every regyon

To thencresse of her most noble name. (Lines 73-76)

Here "fame" and her horse, Pegasus, produce "noble" sounds across "the worlde in every" region. ${ }^{47}$ Rather than represent destructive or low rumour, 
here the goddess serves as another highly effective publicist who popularizes Mary and her "noble name."

If the repeated use of "noble" fails to shape Fame to Newman's productive use, stanza 10 ends by casting Mary in the light of her Christian namesake. Moving beyond the classical divinities evoked earlier, and directly calling upon the mother of Christ, Newman petitions

Maria virgo iustely the same

Amonge the angelles o hevenly empresse,

This puryfyde perle in pastyme proclame

Of rose and pomegarnet the redolent prynsesse. (Lines 77-80)

Traditionally, poets and visual artists represented the Virgin Mary through images of pearls (as well as roses), enabling Newman here to link the Virgin, as the most popular of Catholic saints, to Henry's eldest child, Princess Mary. ${ }^{48}$ Newman's invocation of "Maria virgo," proclaiming the righteousness of the "purified perle," also recalls the ambassadorial letters written to Cardinal Wolsey and King Henry earlier in the summer of 1525 . Where earlier the metaphoric "pearl" represented the great value of Mary as a bargaining chip in European politics, Newman naturalizes or essentializes that value within Mary herself. Here, the text deploys pearls, the mother of God, and her previously established purity to evoke a greater sanctity for the nine-year-old princess as a latter-day "Maria virgo."

Building consciously upon artistic and political traditions of Burgundian statecraft and ideologies constructed through royal theatres of power across late medieval and early modern Europe, the administrations of both Henry VII and Henry VIII manipulated religious imagery as a necessary element in royal iconography. Newman's evocation of the Virgin Mary thus rests upon an effective tradition employed at the English and Spanish courts. ${ }^{49}$ Although Mary's sister would be remembered as a virgin, the Protestant monarch could only deploy such imagery denuded of its Catholic sensibilities. Significantly, Mary's earliest representations embody the same sacred iconography, but without the need to

48. On pearls in royal and Marian iconography, see Frances Yates, Astraea: The Imperial Theme in the Sixteenth Century (New York: Routledge, 1999; rpt.), 78-79.

49. On these traditions, see Roy Strong, Art and Power: Renaissance Festivals 1450-1650 (Rochester: The Boydell Press, 1984; rpt). 
remove their overt connection to traditional religion, which William Newman of Harlowe maintained after the accession of Protestant Queen Elizabeth I. ${ }^{50}$

\section{"fruyte most lyke the deyte"}

The last two stanzas of "My ladie pryncesse" continue to combine classical and Christian figures to represent Mary as a divinely guided royal princess. Extending the organic metaphor established at the poem's outset, Newman recalls the classical goddess to service, asking Dame

Flora extendyng the sencyble odowres

Of every flowre the famous properte,

Regarde the rose with ruby colowres

With the pomegarnet of pure progenyte

Behowlde the fruyte most lyke the deyte,

Of bownteus prematyff the predecesse,

Of noble dowghter in dyngnyte

Of rose and pomegarnet the redolent pryncesse. (Lines 81-88)

Mary's descent from both Henry and the Habsburgs remains ever present in the refrain, providing a unified poetic structure and distinctly hybrid identity for the princess. Escalating his hyperbole, however, here the combination of ruby rose and pure pomegranate refers not only to the combination of royal blood lines but also to a recognition that the combination produces a marvelous "fruyte most like the deity," which recalls the "other fruyte" (line 53) of stanza 7. Such expansive hyperbole thus builds rationally upon Mary's structural and denominative likeness to the Virgin (enunciated in the previous stanza), and the divine right theory enunciated in stanza 3. The earlier, more opaque suggestions that Mary is guided by "fatall" influences (lines 6, 47), or Providence (line 62), here emerge as her unparalleled likeness to God. Such a claim not only provides yet another divine imprimatur for Mary's future rule, but also a sense that the "noble dowghter's" "dyngnyte" transcends her human inheritance. 
Newman fully reveals his motivation for writing such an impassioned and powerful characterization of the nine-year-old only in the last stanza of the manuscript poem. In a poem that repeatedly defines the princess as a truly hybrid or European scion to the English throne, the final stanza speaks a type of nuanced nationalistic feeling that unapologetically combines ethnic pride with the kind of international or European self-identification assiduously fashioned by Mary's father and grandfather. ${ }^{51}$ The dual lineage of Mary, along with her many superlative characteristics, results, for Newman, in the fact that,

Desyre hathe movyd every englysshe hart

To speke and prayse the gret nobelyte

Of her in whome no goodnes may revart. (Lines 89-91)

Marked by a seemingly unassuageable anxiety over, and a consistent assertion of, Mary's inherent nobility of birth, these lines once again return to her "gret nobilite," obsessively reiterating both its public impact and its intractability. Newman manipulatively imagines, in fact, that "every"-read, "true""englysshe hart" longs to share in his project "to speke and prayse" Princess Mary's legal and physical identity. The fact, expressed in line 91, that "no goodness may revert" from Mary again suggests that such goodness or nobility could revert or fall away from non-noble figures like Fitzroy.

The poem reinforces such a reading in the very next lines as Newman forcefully evokes a class-based prejudice built upon the fetishizing of the blood royal and a concomitant rejection of bastardy. Mary's unassailable claim to the English throne rests upon the fact that both of her married parents enjoy noble blood. Her nobility and goodness, he writes, remain inviolate,

Only by fors of her consanguenyte,

Spryngyng owt of the affynete

Most dred and feryde, thus my mastresse

The hyghest blode in the humanyte

Of rose and pomegarnet the redolent pryncesse. (Lines 92-96) 
In no uncertain terms, here the text dramatically defines nobility, and thus Mary, in terms of blood alone-the terms "consanguenyte," "affynete," and "hyghest blode" removing the euphemistic kid gloves of purity, goodness, and family deployed previously.

Such an incessant focus on Mary's unimpeachable, dual royal familiespaired with this final stanza's laser focus on the inheritance of blood-makes most sense if the princess's paternity or that of a rival claimant to the throne emerges as a question or problem. In the summer of 1525, the dynastic rift separating Queen Catherine and King Henry, which would bastardize Mary, had not fully opened. Yet, the summer of 1525 witnessed the ennoblement of Henry Fitzroy, which served as part of the king's multipronged effort to shore up his international reputation as a power with which to be reckoned. The immediately contemporary threat of Fitzroy as alternate heir, then, serves as a sufficient provocation to explain Newman's incessant focus upon the nineyear-old Princess Mary's healthy body, noble blood, and divine support.

\section{"what father and mother she cometh of"}

Customarily hyperbolic, William Newman's trenchant verse propaganda nevertheless publicizes a royal image both recognized and circulated by his contemporaries, yet which remains underappreciated by historians and literary scholars. On 3 September 1526, for example, English ambassador to the Holy Roman Emperor (later, agent of Henry's divorce from Catherine), Richard Sampson, reported to Wolsey on seeing Mary, "surely, Sir, of her age as goodly a child as ever I have seen, and of as good gesture and countenance." Two months later, on 3 November 1526, the Valois King, Francis I, assured English ambassadors

I know well enough her [Mary's] education, her form and fashion, her beauty and virtue, and what father and mother she cometh of, and $\mathrm{h}[\mathrm{ow}]$ expedient and necessary it shall be for me and for my realm that I marry her. And I assure you for the same causes I have as great a mind to her as ever I had to any woman. ${ }^{52}$ 
Together, these elite writers reinforce Newman's portrait of the princess, celebrating her "good gesture," "countenance," "beauty," "virtue," "what father and mother she cometh of," and the desire to marry her precisely as "My ladie pryncesse doughter to king harry the VIII" detailed.

The foregoing contextual reading, then, joins Judith Richards and others in recovering "another version of Mary Tudor, one which presents her as frequently rational, often resourceful in protecting her interests against an increasingly hostile regime, and [...] at least as well prepared to govern the realm as Henry VII, possibly Henry VIII, and Elizabeth." Rather than finding that "this alternative version of Mary starts with the last years in her father's court," ${ }^{33}$ however, the foregoing analysis establishes that Newman's 1525 text worked assiduously "against an increasingly hostile regime" by representing the princess as "well prepared" and as uniquely qualified to "govern the realm." As such, analysis of Newman's text suggests that Mary and Catherine's affinity militated for a clear recognition of Mary's unique royal status as heir apparent much before the arrival of Anne Boleyn and earlier than historians have previously suggested. ${ }^{54}$

53. Judith Richards, "Reassessing Mary Tudor: Some Concluding Points," Mary Tudor: Old and New Perspectives, 215.

54. I want to thank my anonymous readers for their feedback and for helping me to clarify my position. 